\title{
White rodlike crystals in multiple myeloma cells
}

\author{
Juan Zhang, Mingyong $\mathrm{Li}^{*}$ and Yuan $\mathrm{He}$ \\ Clinical Laboratory of Sichuan Academy of Medical Science \& Sichuan Provincial People’s Hospital, Chengdu, Sichuan, China
}

\begin{abstract}
Objective: Several intracytoplasmic morphological changes in the plasma cells of multiple myeloma have been described previously, especially the Auer rod-like inclusions, but no studies focusing on white rodlike crystal inclusions have been reported to date. In this paper, we intend to report a rare case of inclusions in multiple myeloma.

Methods: Bone marrow aspiration from the right superior iliac spine was examined. Cells were stained with "Wright-Giemsa" method and also analyzed by flow cytometry, immunohistochemical staining and fluorescence in situ hybridization(FISH). Bone scan, complete blood count, serum chemistry and coagulation tests were also examined.

Results: Bone marrow aspirate from the right superior iliac spine at the time of myeloma diagnosis showed about $26.5 \%$ of all nucleated cells being plasma cells, of which many had white rodlike crystal inclusions. Repeat bone marrow biopsy later showed persistence of these morphological findings. All of Flow cytometry, immunohistochemistry and FISH examination support the diagnosis of multiple myeloma.
\end{abstract}

Conclusion: This is the first time to report a multiple myeloma case with such white rodlike crystal inclusions. It is a rare and unique case. Due to its rarity, it remains unknown whether this morphological finding confers any prognostic implication.

\section{Introduction}

Cytoplasmic crystalline inclusion bodies in plasma cells have been repeatedly reported, mainly concentrated in the Auer rod-like inclusions. Additionally, other shapes including spindle shaped, prismatic crystal, coarse azurophilic granules have also been reported, but the nature and prognosis of the inclusions are still not clear.

\section{Case report}

A 65-year-old woman presented with a 1-year history of lower back pain, fatigue, dizziness and weight loss. Magnetic resonance imaging of the spine showed lytic lesions involving multiple vertebrae. Immunohistochemical results showed thatCD38(+), CD138(+), CD15(scattered + ), CD20(+), CD79a(+), CD3 (-), $\kappa$ light chain $(+), \lambda$ light chain (-).The results of flow cytometry were consistent with those of immunohistochemistry. Fluorescence in situ hybridization(FISH) displayed 1q21/del(RB1). Routine tests: A complete blood count showed a little anemia. RBC was $3.68 \times 10^{12} / \mathrm{L}$ haemoglobin was 116 $\mathrm{g} / \mathrm{L}$, white cell count $3.27 \times 10^{9} / \mathrm{L}$, neutrophils $0.671 \times 10^{9} / \mathrm{L}$, platelets $80 \times 109 /$ L. Biochemical investigations showed elevated urea and creatinine levels and reversal of the albumin:globulin ratio. Urea 10.08 $\mathrm{mmol} / \mathrm{L}$, creatinine $93.9 \mu \mathrm{mol} / \mathrm{L}$, modifed serum calcium $2.25 \mathrm{mmol} / \mathrm{L}$, and normal bicarbonate levels and anion gap. Coagulation tests results: PT 13s, INR 1.18, APTT 29s, D-Dimer 1.93mg/L FEU, FDP $6.0 \mathrm{Ug} /$ mL. Humoral immunity: IgG 9.45g/L,IgA $1.31 \mathrm{~g} / \mathrm{L}, \operatorname{IgM} 0.5 \mathrm{~g} / \mathrm{L}, \beta 2-$ MG 3.16mg/L, $\kappa$ light chains $2.69 \mathrm{~g} / \mathrm{l}, \lambda$ light chains $1.07 \mathrm{~g} / \mathrm{l}, \kappa / \lambda 2.51$. immunofixation electrophoresis IFE): IgGK Strongly positive. Based on the clinical, biochemical, and radiologic parameters, and combined with the morphology and flow cytometry findings, a diagnosis of multiple myeloma was made.

A bone marrow aspiration revealed plasma cell clones accounted for $26.5 \%$ of total nucleated cells, including $21 \%$ of plasma cells containing of white columnar crystal inclusions. Most plasma cells with these inclusions had distinct nuclei located at one side of the cell and rough chromatin. Other plasma cell cytoplasm is filled with white columnar crystals of varying sizes and numbers, which push the nucleus to one side (panels A-D). For binuclear plasma cells, more than ten inclusion bodies frequently appeared between the two nuclei and even white columnar crystals can be seen on the nucleus (panels C). Repeat bone marrow biopsy later showed persistence of these morphological findings (Figure 1).

\section{Discussion}

Rare instances of Auer-like inclusions within plasma cells have been previously reported. The mechanism by which they occur and their pathophysiologic significance are not understood. Besides, other forms include needle-like, coarse, azurophilic granules, prismatic, spindle shaped, spherical, cylindrical shape and so on have also been reported[1]. The varied crystalline intracytoplasmic inclusions can also be seen in other types of hematologic disorders [2]. But still now, no reports of white columnar crystals have been reported in any type of cells.

Since the first description of inclusions in myeloma by Steinmann in a case of a 51-year-old woman with a parasternal tumor [3], cytoplasmic crystalline inclusion bodies in neoplastic or mature plasma cells have been described. Steinmann was also the first time to prove that these inclusions to be of lysosomal origin (fusionated lysosomal

Correspondence to: Mingyong Li, Clinical Laboratory of Sichuan Academy of Medical Science, Sichuan Provincial People’s Hospital, Chengdu, China, Tel: +86 028-87394644; E-mail: zhangjuan82@126.com

Key words: multiple myeloma(MM), intracytoplasmic inclusion, $M$ protein, white rodlike crystal inclusions

Received: October 02, 2017; Accepted: October 24, 2017; Published: October 26,2017 


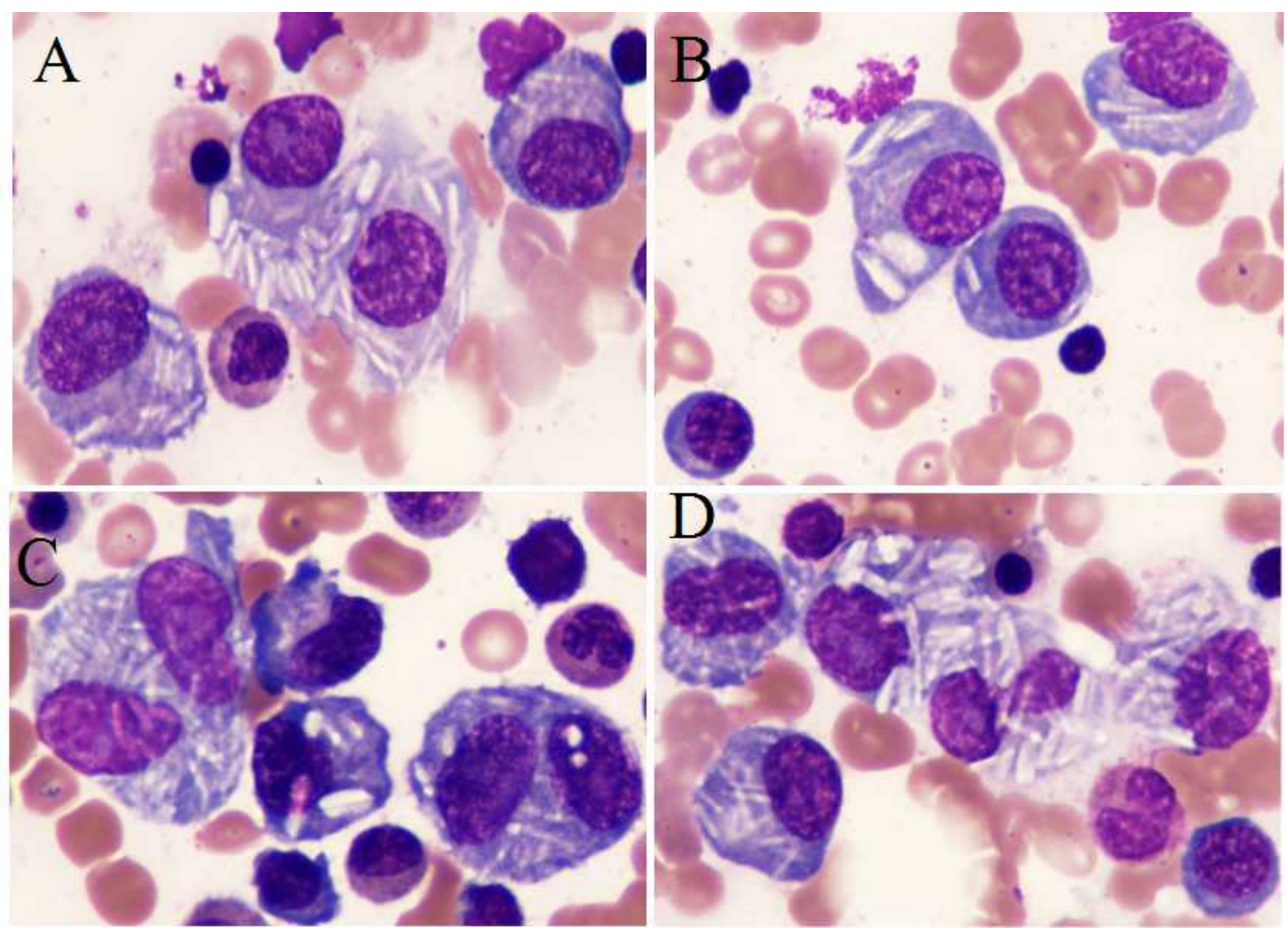

Figure 1. Bone marrow aspirate, $(\times 1000$, Wright-Giemsa stain).

granules). Following that report, many more cases have been described [1,2,4-10]. Pooling together all the cases reviewed by Hütter [1] and other reports, including our cases, it appears that this phenomenon is always associated with a IgG $\kappa$-type paraprotein, only two cases of $\lambda$ light chain restriction [4-14]. Although plasma cell myeloma with these inclusion bodies has been considered to be a morphologic variant and has intrigued investigators, the prognostic value is still unclear [9-14]. Additionally, there is still no known cytogenetic association nor any particular immunophenotypic characteristic relationship.

This case demonstrates the unusual inclusion morphology of plasma cell myeloma, which can lead to difficulties in morphologic diagnosis. To the best of our knowledge, this is the first time to report such a multiple myeloma case with variable shaped white column intracytoplasmic inclusions. It remains unclear how these inclusions are generated and what chemical properties they possess. Moreover, how these inclusions correlate with the clinical implications and prognosis remains to be determined.

\section{Conflicts of interest}

All authors have no conflicts of interest to declare.

\section{References}

1. Hütter G, Nowak D, Blau IW, Thiel E (2009) Auer rod-like intracytoplasmic inclusions in multiple myeloma. A case report and review of the literature. Int J Lab Hematol 31: 236-240. [Crossref]

2. Gupta A, Gupta M, Handoo A, Vaid A (2011) Cystalline inclusions in plasma cells. Indian J Pathol Microbiol 54: 836-837. [Crossref]

3. Steinmann B (1940) Uber azurophile stabchenformige Einschlusse in den Zellen eines multiplen myeloms. Dtsch Arch Klin Med 185: S49-S61.

4. Metzgeroth G, Back W, Maywald O, Schatz M, Willer A, et al. (2003) Auer rod-like inclusions in multiple myeloma. Ann Hematol 82: 57-60. [Crossref]
5. Ali N1, Moiz B (2009) Azurophilic inclusions in plasma cells. Singapore Med J 50: e114-115. [Crossref]

6. Frotscher B, Salignac S, Lecompte T (2009) Multiple myeloma with unusual inclusions. Br J Haematol 144: 1. [Crossref]

7. Kulbacki EL, Wang E (2010) IgG-lambda plasma cell myeloma with cytoplasmic azurophilic inclusion bodies. Am J Hematol 85: 516-517. [Crossref]

8. Parmentier S, Radke J (2012) Pseudo-Auer rods in a patient with newly diagnosed IgG myeloma. Blood 119: 650. [Crossref]

9. Noujaim JC, D'Angelo G (2013) Auer rod-like inclusions in Î $^{\circ}$ light chain myeloma Blood 122: 2932. [Crossref]

10. Abdulsalam AH, Bain BJ (2014) Auer-rod like inclusions in multiple myeloma. Am J Hematol 89: 338. [Crossref]

11. Oh SH, Park CJ (2010) Auer rod-like crystal inclusions in plasma cells of multiple myeloma. Korean J Hematol 45: 222. [Crossref]

12. Staubach ZG, Rodman JB (2017) Intracellular light chain crystals in myeloma. Blood 130: 1070. [Crossref]

13. Ramos J, Lorsbach R (2014) Hemophagocytosis by neoplastic plasma cells in multiple myeloma. Blood 123: 1634. [Crossref]

14. Kumar G, Ahluwalia J (2015) "Multiple forms" of a myeloma. Blood 126: 692 [Crossref]

Copyright: (C2017 Zhang J. This is an open-access article distributed under the terms of the Creative Commons Attribution License, which permits unrestricted use, distribution, and reproduction in any medium, provided the original author and source are credited. 